\title{
KAPUR SEBAGAI BAHAN TAMBAH UNTUK BETON NORMAL
}

\author{
Tri Mulyono
}

\begin{abstract}
Abstrak
Penelitian ini berdasarkan standar nasional Indonesia (SNI 03-2834-1993) "Tata Cara Pembuatan Rencana Campuran Beton Normal", proporsi kapur sebagai bahan tambah yang disubstitusikan dalam semen untuk beton normal dimulai dari prosentase 10\% kapur sampai $70 \%$ kapur dalam berat. Hasil uji tekan dilakukan untuk beton menggunakan silinder umur 28 hari. Data di analisis menggunakan silinder dan untuk kubus dilakukan konversi menjadi silinder. Hasil uji dan analisa penelitian dengan data yang terdistribusi normal dan homogen memberikan hal sebagai berikut: (a) hasil uji untuk variasi kapur yang berbeda akan menghasilkan dan berpengaruh terhadap kemudahan pekerjaan, dimana semakin besar penambahan kapur akan menurunkan tingkat kemudahan pekerjaan. (b) penambahan kapur tidak berpengaruh terhadap berat isi beton keras (c) rata-rata berat jenis yang dihasilkan sebesar $2330 \mathrm{~kg} / \mathrm{m}^{3}$. (d) Komposisi optimal dari kapur sebesar 19\% ditambahkan sebagai substitusi semen menghasilkan nilai kekuatan tekan sebesar 22.3 Mpa.
\end{abstract}

Kata Kunci: Kapur, Kuat Tekan, Beton Normal

\section{PENDAHULUAN}

Biaya semen dalam sebuah campuran beton merupakan faktor yang menentukan karena mahalnya proses produksi yang pada gilirannya menentukan harga jual. Berdasarkan hal ini dan pertimbangan biaya maka dicoba untuk mencari alternatif campuran semen yang murah dan secara struktural dapat memenuhi kinerja kekuatan tekan. Unsur yang dipertimbangkan sebagai substitusi semen adalah material yang mempunyai sifat penyemenan atau hidrolis. Kapur menjadi alternatif pilihan karena unsur kimia dalam kapur hampir sama dengan yang terdapat dalam semen. Permaslahan utama adalah berapa banyak kapur yang perlu ditambahkan kedalam semen yang masih significant menambahkan kekuatan tekan.

Berdasarkan uraian di atas muncul sejumlah pertanyaan tentang pengaruh kapur jika digunakan sebagai bahan pengganti semen, yang dapat di identifikasi adalah sebagai

\section{Tri Mulyono}

Staf Pengajar Jurusan Teknis Sipil

Fakultas Teknik Universitas Negeri Jakarta

Email: tri_mulyono_sipilunj@yahoo.co.id 
berikut: (a) Bagaimana pengaruh kapur sebagai bahan pengganti semen dalam campuran beton untuk meninggkatkan kuat tekannya. (b) Bagaimana pengaruh kapur sebagai bahan pengganti semen dalam campuran beton untuk meninggkatkan kuat tekannya jika menggunakan berbagai variasi ukuran agregat. (c) Bagaimana menentukan rancangan campuran untuk beton normal yang menggunakan kapur sebagai bahan pengganti semen kaitannya dengan peningkatan kuat tekan beton normal (d) Bagaimana menentukan kandungan yang optimal kapur untuk meningkatkan kuat tekan beton (e) Bagimana kuat tekan beton dengan menggunakan komposisi kapur yang optimal dibandingkan dengan beton yang tidak menggunakan kapur.

Karena keterbatasan alokasi pembiayaan maka penelitian ini dibatasi hanya untuk mengkaji bagaimana pengaruh kapur sebagai pengganti semen dengan komposisi 10\% sampai $70 \%$ dengan menggunakan agregat berukuran $10 \mathrm{~mm}$. Penelitian ini hanya melihat kuat tekannya. Berdasarkan hal tersebut maka dapat dirumuskan bahwa penelitian ini hanya mengkaji untuk menentukan kandungan yang optimal kapur yang masih dapat untuk mengingkatkan kuat tekan beton normal yang digunakan sebagai struktur.

Berdasarkan uraian di atas tujuan penelitian ini adalah untuk memberikan penjelasan dan mendeskripsikan berapa sebenarnya komposisi yang optimal kapur sebagai bahan pengganti semen yang masih dapat meningkatkan kuat tekan dibandingkan dengan beton normal. Pada akhirnya untuk mencari beton yang murah dan terjangkau secara ekonomi.

\section{Kekuatan Tekan Beton}

Kekuatan tekan beton menjadi pertimbangan utama dalam sebuah struktur termasuk juga bahan atau materialnya sama dengan beton. Sifat fisika beton tergantung dari faktor antara lain campurannya, agregat, type semen, perawatan, dan umurnya juga pengaruh lingkungan seperti temperatur dan kelembaban relatif. Durabilitas beton berhubungan dengan faktor yang mempengaruh kekuatan tekan dan juga kandungan semen dan udara dalam beton. Mengetahui kekuatan tekan didasarkan hasil test kubus atau silinder uji. (Freedman, 1974). Metode standar uji kekuatan tekan beton normal di adopsi dari standar ASTM C.39 94 dalam SNI adalah "Standar Nasional Indonesia" (SNI) - SK. SNI- 03 - 2834 - 1993. Kekuatan tekan beton normal dari hasil test berkisar antara 20 - 40 Mpa dengan berat jenis 2200 - 2500 kg/cm3. (Mulyono, 2004). 


\section{Sifat-Sifat Beton}

Pasta semen: Beton adalah campuran semen portland atau sembarang semen hidrolik yang lain, agregat halus, agregat kasar dan air dengan atau menggunakan bahan tambahan. Kekuatan tekan beton setelah keras ditentukan oleh kekuatan pasta semen. Pasta semen merupakan campuran air dengan semen yang dinyatakan dalam rasio air dengan semen.. Abrams (1920) merekomendasikan faktor air semen (FAS) untuk beton normal berkisar antara 0.2 sampai 0.6. FAS menentukan kekuatan tekan, semakin banyak air kekuatan tekan akan turun akan tetapi kemudahan pekerjaan semakin baik dinyatakan dalam nilai slum begitu juga sebaliknya. Nilai slump beton normal umumnya berkisar 120 - $180 \mathrm{~mm}$. Faktor lain yang mempengaruhi kekuatan tekan adalah kualitas agregat, kualitas pencampuran, pemadatan, perawatan dan lingkungan. Pasta semen dihasilkan dari material yang bersifat cementious seperti pozzolan, clinker, lime dan lainnya. (Mulyono, 2004). Menurut ASTM C-150,1985, Semen portland adalah semen hidrolik yang di hasilkan dengan menggiling klinker yang terdiri dari kalsium silikat hidrolik, yang umumnya mengandung satu atau lebih bentuk kalsium sulfat sebagai bahan tambahan yang digiling bersama-sama dengan bahan utamanya (ASTM C.125-94).

Kapur: Kapur dapat dijadikan sebagai material pengganti sebagian semen dalam campuran beton. Kapur dihasilkan berdasarkan proses kimia dan mekanis di alam. Kapur telah digunakan berabad-abad lamanya sebagai bahan adukan dan plesteran untuk bangunan, dapat dilihat dari pembangunan pyramida-pyramida di Mesir, di bangun lebih dari 4500 tahun sebelum masehi. Kapur digunakan sebagai bahan pengikat selama masa jaman Romawi dan Yunani. Orang-orang Romawi menggunakan beton untuk membangun Colleseum dan Pantheon, dengan cara mencampur kapur dengan abu gunung yang di dapat dekat Pozzuoli, Italia, yang mereka namakan Pozollan. Lebih dari 80\% kapur digunakan di Amerika sebagai unsur konstruksi, saat ini lebih dari 90\% kapur digunakan di industri kimia. Secara kimiawi kapur dibedakan dari unsur-unsur kimianya yaitu: (1) quicklime, calcium oxide (CaO); (2) hydrated lime, calcium hydroxide [Ca(OH)2]; (3) dolomitic quicklime ( $\mathrm{CaO} . \mathrm{MgO})$; dua tipe dari hidrasi dolomitic, (4) type $\mathrm{N}$ [Ca(OH)2 . MgO] dan (5) type S Ca(OH)2, $\mathrm{Mg}(\mathrm{OH}) 2]$; serta(6) pembakaran dolomite. Non-dolomitic quicklime dan hidrasi kapur juga disebut high-calcium lime. Kapur juga diproduksi dari beberapa material seperti aragonite, chalk, coral, marble, dan shell. Penggunaan kapur antara lain paper mills, carbide plants, dan water treatment plants, 
beton, dan lain-lain. (Miller, 2005). Pada penelitian ini teminologi kapur adalah seperti yang tertuang dalam ASTM C-294 yaitu batu kapur (limestone) (ASTM - C.294-91). Batu kapur atau kapur merupakan Kapur hidrolik sebagian besar bahannya terbuat dari batu gamping sekitar 65\%-75\%, yaitu kalsium karbonat beserta bahan pengikutnya berupa silika, alumina, magnesia dan oxida besi. Di Indonesia kapur umumnya digunakan sebagai bahan campuran pasangan untuk pekerjaan pasangan seperti yang tertuang dalam BOW/analisa harga satuan, akan tetapi berapa nilai kekuatan tekannya tidak secara jelas disebutkan. (Muko-muko, 1993).

Agregat: Agregat dapat di bedakan menjadi dua golongan jika di lihat dari sumbernya yaitu agregat yang berasal dari alam dan agregat buatan (artificial aggregates). Agregat yang berasal dari sumber alam yaitu pasir alami dan kerikil, sedangkan yang buatan dapat berasal dari stone crusher ataupun dari hasil residu terak tanur tinggi (blast furnace slag), pecahan genteng, pecahan beton, fly ash dari residu PLTU, extended shale, expanded slag dan lainnya. Berdasarkan ukuranya agregat dibedakan menjadi agregat kasar dan halus. Agregat kasar adalah agregat yang butirnya tertahan pada ayakan $4.75 \mathrm{~mm}$ dan agregat halus yang lolos 4,75 mm (ASTM - C.125-94).

Sifat dan karakteristik bahan beton terlebih dahulu diketahui agar dapat diperkirakan substitusi kapur yang digunakan yang pada akhirnya akan menentukan kekuatan tekan beton normal. Penggunaan prosedur standar seperti SNI, ASTM, AASTHO atau British Standard menjadi acuan. Berdasarkan sifat dan karakteristik bahan selanjutnya dibuat rancangan campuran. Untuk menentukan kadar optimum kapur dalam campuran yang dapat meningkatkan kekuatan tekan digunakan kapur dengan prosentase $10 \%$ sampai $70 \%$ dari berat semen. Langkah berikutnya melakukan pencampuran, pembuatan benda uji, perawatan benda uji, dan melakukan uji tekan. Tahap akhir adalah melakukan analisis data.

Berdasarkan uraian di atas hipotesisnya dirumuskan sebagai berikut: (a) Bagaimana menentukan kekuatan tekan beton normal menggunakan berbagai variasi kapur. (b) Terdapat hubungan positif antara penambahan kapur dalam meningkatkan kekuatan tekan beton. (c) Terdapat perbedaan nyata kekuatan tekan sebagai beton normal menggunakan kadar kapur optimum dibandingkan dengan tidak menggunakan kapur. 


\section{METODOLOGI}

Untuk menentukan kandungan optimum kapur yang masih dapat untuk meningkatkan kekuatan tekan beton dalam beton normal ditunjukan pada gambar 2. Langkah pertama adalah menentukan sifat dan karakteristik bahan beton seperti semen dan kapur, air serta agregat. Kedua menentukan komposisi campuran beton normal berdasarkan "Standar Nasional Indonesia" atau SNI (SNI 03-2834-1993) "Tata Cara Pembuatan Rencana Campuran Beton Normal". Kemudian menentukan prosentase proporsi campuran kapur dari $10 \%$ sampai dengan $70 \%$ dalam berat semen. Langkah berikutnya mencampur bahan menggunakan mesin pencampur dan membuat kubus atau silinder beton selanjutnya merawat sampel uji di laboratorium. Terakhir di laboratorium adalah melakukan test tekan menggunakan mesin tekan. Tahapan setelah kerjaan di laboratorium adalah melakukan analisis data keluaran menggunakan metode statistik yang relevan dengan alat bantu SPPS.

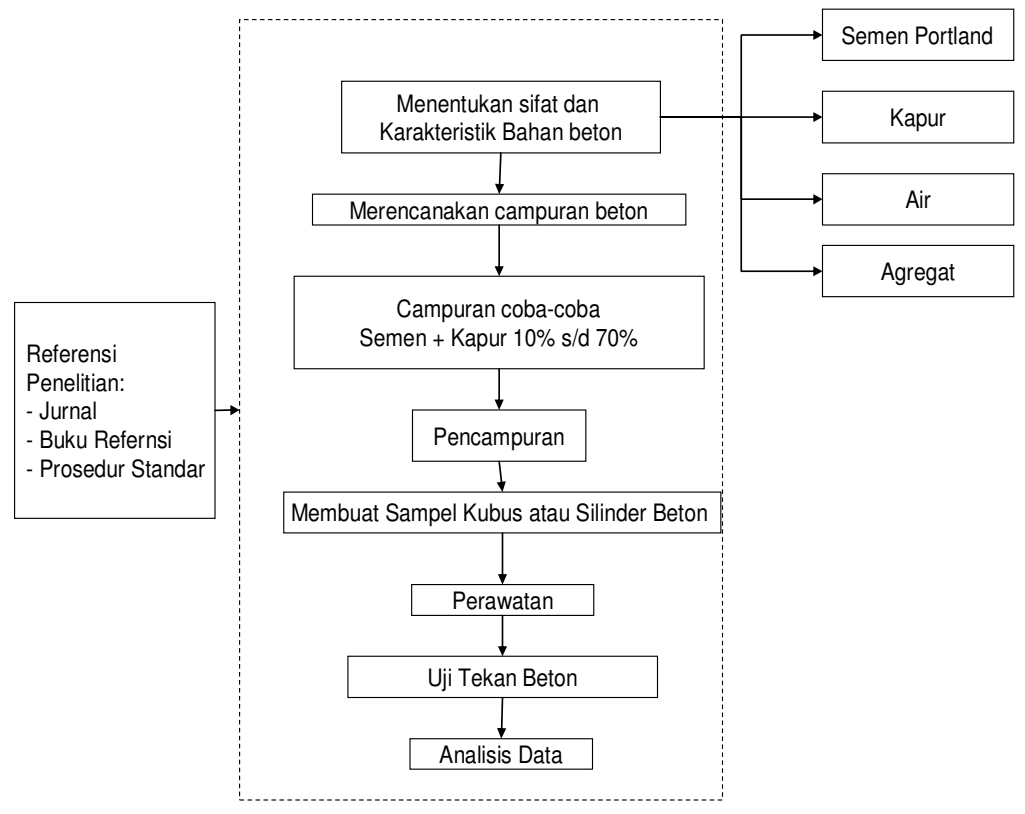

Gambar 2. Diagram Alir Penelitian

Penelitian dilakukan di Laboratorium Uji Bahan Jurusan Teknik Sipil - Fakultas Teknik Universitas Negeri Jakarta. Lama penelitian dilakukan selama enam bulan dari Juli Desember 2006.

Banyaknya sample dalam populasi untuk penelitian ini dibatasi biaya. Banyaknya populasi setiap variasi adalah 20 buah yang diambil masing-masing secara acak 15 buah. 
Peralatan yang digunakan adalah peralatan yang ada di Laboratorium JTS-FT.UNJ sedangkan prosedur standar yang digunakan mengacu pada SNI/ASTM/AASTHO/BS antara lain [13] sesuai dengan (a) Flask Bottle untuk menentukan berat jenis dan penyerapan agregat halus sesuai dengan ASTM C.128 - 93 dan SNI - 03 - 1750 - 1990 "Mutu dan Cara Uji Agregat Beton". (b) Peralatan unntuk menguji menentukan berat jenis dan penyerapan agregat kasar sesuai ASTM C.127 - 88 dan SNI - 03 - 1750 - 1990. (c) Completed Sieve dan Shaker Machine for analysis of fine and course aggregates based of ASTM 136 - 95a and SNI - 03 1750 - 1990. (d) Mixer Concrete based of SNI 03 - 3976 - 1995, "Tata Cara Pengadukan Pengecoran Beton Segar".(e) Slump Test Apparatus for determination of slump value based of ASTM C.143 - 90a and SNI 03 - 1972 - 1990 / SK. SNI M-12-1989-F. (f) Cube or Cylinder Sample for sampling freshly mixed concrete based of ASTM. C.172 - 90 and SNI $03-2492$ 2002 "Metode Pembuatan dan Perawatan Benda Uji di Laboratorium". (g) Compressive Machine for determination of compression strength based of ASTM C.39 - 94 and Peralatan lain seperti timbangan, oven, pan, can dan lainnya.

\section{ANALISIS DATA DAN PEMBAHASAN}

\section{Sifat dan Karakteristik Bahan}

Sifat dan karakterisitik kapur dalam penelitian ini tidak secara detail di uji. Asumsinya bahwa sifatnya sama dengan semen. Kapur yang digunakan didapatkan dari Padalarang Bandung biasa disebut "mill" berbentuk bubuk. Portland cement adalah semen tipe I (Tiga Roda). Air mempunyai pH normal, tidak berasa dan bebas dari unsur kimia, zat yang menggangu lainnya. Agregat kasar menggunakan batu pecah dan agregat halus alami dengan gradasi memenuhi zona II dengan modulus halus butir 2,89. Sifat dan karakteristik hasil uji agregat disajikan pada tabel 2 .

Tabel 2. Sifat dan karekateristik Agregat

\begin{tabular}{|l|l|l|}
\hline Sifat dan Karakteristik & Agregat Halus & Agregat Kasar \\
\hline Berat Isi: - Gembur/Losses (Kg/m $\left.{ }^{3}\right)$ & 1.515 & 1.424 \\
\multicolumn{1}{|c|}{ Padat/Compaction } & 1.660 & - \\
\hline Berat Jenis/Specific Gravity & 2.695 & 2.665 \\
Berat Jenis Jenuh Permukaan Kering/Specific & 2.739 & 2.516 \\
Gravity (Saturated Surface Density) & & \\
\hline Penyerapan Air/Absorption of Water (\%) & 1.629 & 3.678 \\
\hline Kadar Air/Water Content (\%) & 3.25 & 1.15 \\
\hline
\end{tabular}




\section{Rancangan Campuran}

Rancangan campuran percobaan menggunakan SNI - 03 - 2834 - 1993, berdasarkan data uji bahan hasil rancangan komposisi campuran disajikan pada tabel 3 , asumsi kekuatan tekan adalah $20 \mathrm{Mpa}$ untuk umur 28 hari dengan kondisi lingkungan basah dan kering terus menerus, maksimum agregat kasar $10 \mathrm{~mm}$ dengan slump $12 \pm 2 \mathrm{~cm}$. Standar deviasi adalah $5.25 \mathrm{Mpa}$.

Tabel 3. Rancangan Komposisi Campuran Percobaan

\begin{tabular}{|l|l|c|}
\hline Deskripsi & Proporsi dalam $1 \mathrm{~m}^{3}$ & Proporsi dalam $0.015 \mathrm{~m}^{3}$ \\
\hline Portland Cement & $350 \mathrm{~kg}$ & 5.25 \\
Water & $210 \mathrm{liter}$ & 3.15 \\
Fine Aggregate & $806 \mathrm{~kg}$ & 12.09 \\
Course Aggregate & $984 \mathrm{~kg}$ & 14.76 \\
\hline Jumlah & $2350 \mathrm{Kg}$ & 14.76 \\
\hline
\end{tabular}

Tabel 4. Kadar Kapur dalam campuran $0.015 \mathrm{~m}^{3}$.

\begin{tabular}{|c|c|c|}
\hline Kadar Kapur & Berat Portland Cement $(\mathrm{kg})$ & Berat Kapur $(\mathrm{kg})$ \\
\hline $0 \%$ & 5.250 & 0.000 \\
$10 \%$ & 4.725 & 0.525 \\
$20 \%$ & 4.200 & 1.050 \\
$30 \%$ & 3.675 & 1.575 \\
$40 \%$ & 3.150 & 2.100 \\
$50 \%$ & 2.625 & 2.625 \\
$60 \%$ & 2.100 & 3.150 \\
$70 \%$ & 1.575 & 3.675 \\
\hline
\end{tabular}

\section{Uji Slump dan Berat Isi}

Hasil uji kekuatan tekan rata-rata dan berat isi untuk berbagai variasi kadar kapur disajikan pada table 5. Untuk hasil uji kekuatan tekan kubus ( $f_{c k}$ dalam Mpa) dilakukan konversi kedalam silinder ( $f_{c}^{\prime}$ dalam Mpa) menggunakan persamaan: $f_{c}^{\prime}=\left[0.76+0.2 \log \left(f_{c k}^{\prime} / 15\right)\right] f_{c k}^{\prime}$,

Tabel 5.Hasil Uji Slum dan Berat Isi dengan Variasi Kadar Kapur

\begin{tabular}{|c|c|c|c|}
\hline Kadar Kapur & Slump Test $(\mathrm{mm})$ & Unit Weight $\left(\mathrm{Kg} / \mathrm{cm}^{3}\right)$ & $\begin{array}{c}\text { Rata-Rata kekuatan Tekan } \\
\text { (Mpa) }\end{array}$ \\
\hline $0 \%$ & 110 & 2.344 & 20.340 \\
$10 \%$ & 70 & 2.332 & 21.869 \\
$20 \%$ & 75 & 2.283 & 22.337 \\
$30 \%$ & 60 & 2.360 & 21.249 \\
$40 \%$ & 60 & 2.340 & 15.181 \\
$50 \%$ & 55 & 2.338 & 14.929 \\
$60 \%$ & 50 & 2.359 & 14.568 \\
$70 \%$ & 50 & 2.342 & 12.229 \\
\hline
\end{tabular}




\section{Pengujian Persyaratan Analisis}

Uji kenormalan distribusi data menggunakan Kolmogorov-Smirnov Test. Hasil uji menyatakan bahwa data terdistribusi normal. Bartlett Test digunakan untuk mengguji homogenitas, hasil uji menyatakan bahwa data adalah homogen. Deskripsi statistik hasil uji disajikan pada table 6 .

Tabel 6. Deskripsi Statistik Hasil Uji

\begin{tabular}{|l|r|r|r|r|r|r|r|r|r|}
\hline & & \multicolumn{7}{|c|}{ Kekuatan Tekan dengan variasi Kadar Kapur } \\
\hline & & 0 & \multicolumn{1}{|c|}{$10 \%$} & \multicolumn{1}{c|}{$20 \%$} & \multicolumn{1}{c|}{$30 \%$} & \multicolumn{1}{c|}{$40 \%$} & \multicolumn{1}{c|}{$50 \%$} & \multicolumn{1}{c|}{$60 \%$} & \multicolumn{1}{c|}{$70 \%$} \\
\hline $\mathrm{N}$ & Statistic & 15 & 15 & 15 & 15 & 15 & 15 & 15 & 15 \\
Range & Statistic & 7.006 & 10.616 & 11.465 & 6.662 & 12.055 & 8.565 & 11.139 & 8.281 \\
Minimum & Statistic & 15.924 & 16.136 & 15.924 & 16.136 & 10.743 & 8.887 & 6.441 & 7.643 \\
Maximum & Statistic & 22.930 & 26.752 & 27.389 & 22.798 & 22.798 & 17.452 & 17.580 & 15.924 \\
Mean & Statistic & 20.33960 & 21.86860 & 22.33733 & 21.24893 & 15.18153 & 14.92887 & 14.56800 & 12.22940 \\
& Std. Error & .45451 & .70753 & .78091 & .51133 & .77426 & .50166 & .73602 & .51338 \\
Std. Deviation & Statistic & 1.76030 & 2.74023 & 3.02445 & 1.98037 & 2.99869 & 1.94292 & 2.85059 & 1.98830 \\
Variance & Statistic & 3.099 & 7.509 & 9.147 & 3.922 & 8.992 & 3.775 & 8.126 & 3.953 \\
Skewness & Statistic & -.787 & -.727 & -.832 & -1.806 & 1.279 & -2.182 & -1.896 & -.572 \\
& Std. Error & .580 & .580 & .580 & .580 & .580 & .580 & .580 & .580 \\
\hline
\end{tabular}

\section{Analisis Data}

\section{Hubungan antara kadar kapur dan rata-rata kekuatan tekan}

Hubungan antara berbagai variasi kadar kapur yang ditambahkan dalam campuran dengan kekuatan tekan hasil uji memberikan nilai kekuatan tekan yang dapat dicapai untuk kadar kapur optimum sebesar 19\% sebesar 22,3 Mpa. Hubungannya disajikan pada gambar 3.

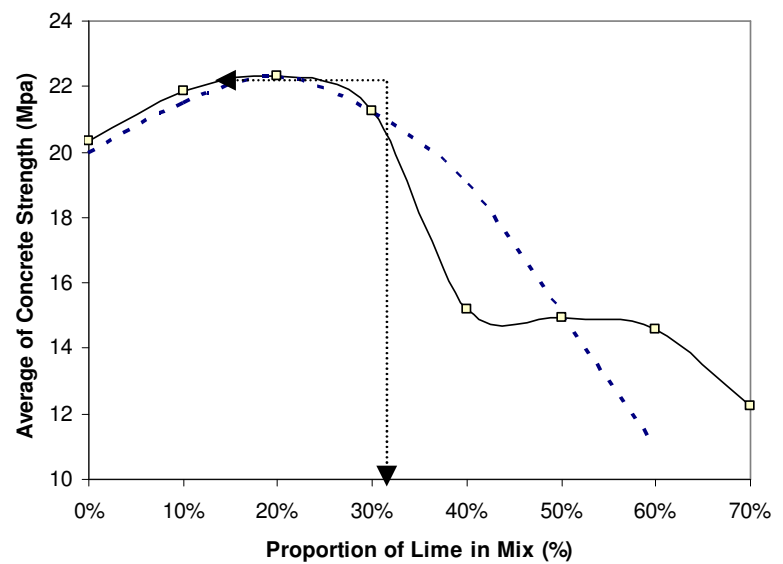

Gambar 3. Hubungan antara kadar kapur dan rata-rata kekuatan tekan. 


\section{Hubungan antara kadar kapur dan berat isi}

Hubungan antara variasi kadar kapur dalam campuran dengan berat isi (gambar 4) ratarata sebesar $2330 \mathrm{Kg} / \mathrm{m}^{3}$ (interval $2300-2400 \mathrm{Kg} / \mathrm{m}^{3}$ ) nilai ini mendekati angka asumsi dalam hitungan perencanaan campuran.

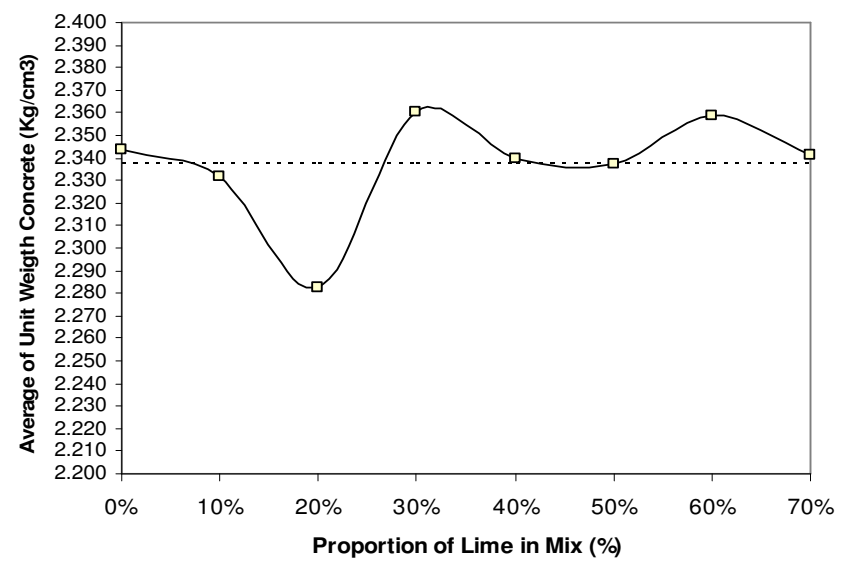

Gambar 4. Hubungan antara kadar kapur dan berat isi

Hubungan antara berat isi, nilai slump dan kekuatan tekan

Berdasarkan gambar 5 dan 6, hubungan berbagai variasi kadar kapur dengan berat isi, nilai slump dan kekuatan tekan adalah: (1) penambahan kekuatan tekan tidak berpengaruh terhadap berat isi, (2) penambahan nilai slump akan berpengaruh terhadap kekuatan tekan, hal ini dapat dimengerti bahwa dengan semakin banyak kadar kapur maka daya serap air semakin besar sehingga menambah faktor air semen dan menyebabkan kemudahan pekerjaan menjadi berkurang.

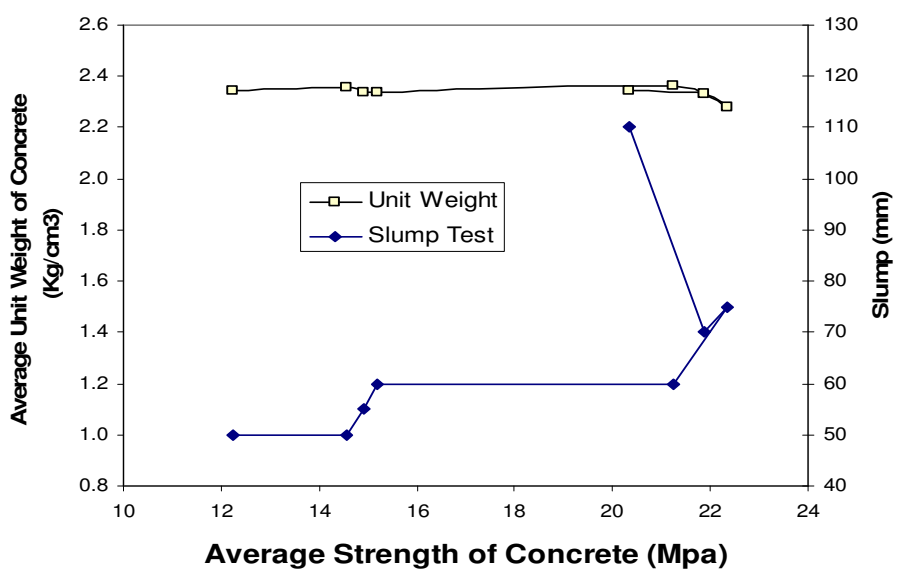

Gambar 5. Hubungan antara kekuatan tekan dengan nilai slump dan berat isi 


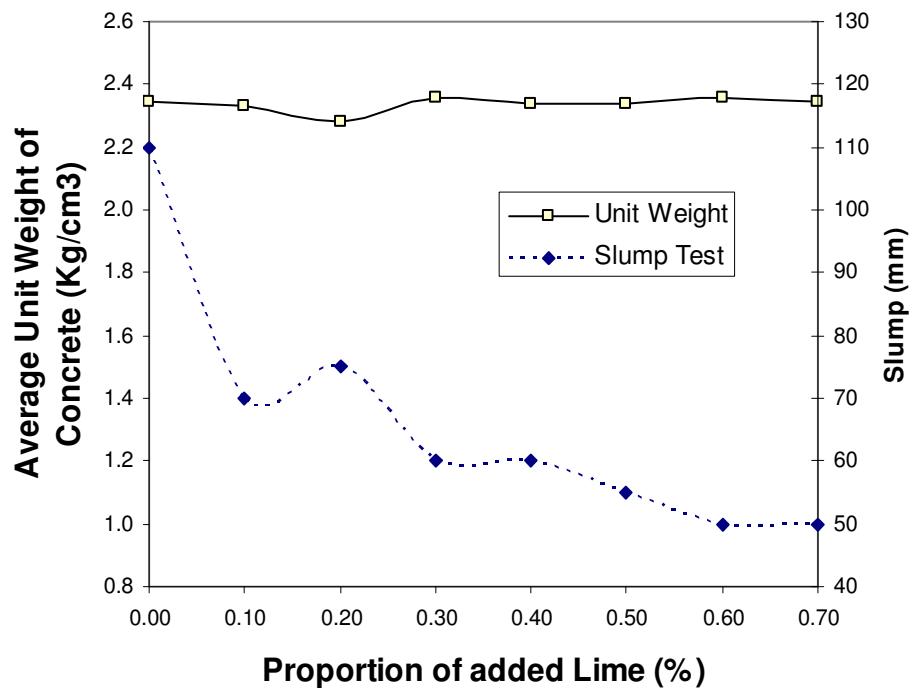

Gambar 6. Hubungan antara kadar kapur dengan berat isi dan nilai slump

\section{KESIMPULAN DAN SARAN}

Kesimpulan yang dapat diambil adalah Petama: Deskripsi asumsi untuk beton normal dalam penelitian ini adalah: (a) Rencana kekuatan tekan umur 28 hari adalah $20 \mathrm{Mpa}$ menggunakan uji silinder dengan standar deviasi sebesar 5.25 Mpa. (b) Portland Sement menggunakan semen type I merk Tiga Roda (c) Agregat halus menggunakan agregat alami dengan berat jenis 2.739 dan agregat kasar menggunakan agregat buatan (pecahan) dengan butir maksimum $10 \mathrm{~mm}$ dan berat jenis 2.516. (d) Kondisi pekerjaan diasumsikan tidak terlindung dari perubahan cuaca basah dan kering. Rancangan campuran menggunakan metode SNI - 03 - 2834 - 1993. Sifat dan karakteristik bahan di uji di Laboratorium Uji Bahan - Jurusan Teknik Sipil Fakultas Teknik Universitas Negeri Jakarta. Komposisi untuk satu meter kubik campuran percobaan adalah (1) Portland cement $350 \mathrm{Kg}$ (2) air 210 liter, (3) agregat halus 806 kg dan(4) agregat kasar 984 kg. Kedua: Variasi kadar kapur yang ditambahkan dalam campuran beton normal berdasarkan prosentase berat semen dengan variasi $0 \%, 10 \%$, $20 \%, 30 \%, 40 \%, 50 \%, 60 \%$ dan $70 \%$. Pengujian beton segar hanya dilakukan untuk uji slump untuk mengetahui kemudahan pekerjaan. Pada beton keras dilakukan uji kekuatan tekan dan berat isinya. Ketiga: Populasi untuk benda uji 20 buah dan diambil secara acak sebanyak 15 buah untuk dilakukan pengujian tekan. Selanjutnya hasil data diuji di analisis menggunakan statistik. Hasil uji persyaratan analisis data terdistribusi normal dan homogen. Keempat. Rata- 
rata berat isi untuk berbagai variasi kadar kapur sebesar $2330 \mathrm{~kg} / \mathrm{m}^{3}$. Nilai optimum kadar kapur yang didapat sebesar 19\% dengan nilai kekuatan tekan sebesar 22.3 Mpa.

Beberapa saran dapat diberikan adalah penentuan nilai kadar kapur optimal dalam sebuah campuran beton pada penelitian ini tidak melihat secara detail pengaruh kimia dan analisi kimianya, sebaiknya penelitian lebih lanjut pengaruh kimia dapat dilakukan. Pada penelitian ini hanya menggunakan agregat dengan butir maksimum $10 \mathrm{~mm}$ untuk selanjutnya dapat menggunakan berbagai butir maksimum dari 20, 30 dan $40 \mathrm{~mm}$. Termasuk juga penelitian pengaruh penggunaan kapur untuk pekerjaan pasangan (mortar) atau lainnya.

\section{DAFTAR PUSTAKA}

Freedman, Sidney, Properties of Material for Reinforced Concrete, in Handbook of Concrete Engineering, edited By Mark Fintel, USA: Van-Nonstrand Reinhold Company, 1974.

Mulyono, Tri, Teknologi Beton, Second Edition, Yogyakarta: Andi Offset, 2003.

ASTM - C.125-94, Standard Terminology Relating to Concrete and Concrete Aggregates, Philadelphia-USA: ASTM Volume 04.02 Concrete and Aggregates, 1995. pp, 61-63.

Miller, M. Michael, LIME in 1997, Download from http://www.lime.org published by the U.S. Bureau of Mines 1999. Download date at 20 Oktober 2005.

ASTM - C.294-91, Standard Descriptive Nomenclature for Constituents of Natural Mineral Aggregates, Philadelphia-USA: ASTM Volume 04.02 Concrete and Aggregates, 1995, pp. 169-175.

Muko-Muko, J.A, Dasar-dasar Menyusun Rencana Anggaran Biaya Bangunan Jakarta: GMP, 1993. 